\title{
BEHAVIOR OF MICRO ENTREPRENEURS JOMBANG AGAINST COST REDUCTION; RELIGIOUS AND SOCIAL VALUE
}

\author{
Linda A. Razak, \\ Universitas Muhammadiyah Makassar \\ Muh.Yamin \\ Postgraduate Student, Hasanuddin University \\ Arzalsyah \\ Postgraduate Student, Hasanuddin University
}

\begin{abstract}
Behavior of Micro Entrepreneurs Jombang Against Cost Reduction: Religious and Social Value. This research tries to reveal the meaning of cost reduction in the perspective of micro entrepreneurs Jombang. Research method using phenomenology, that is by finding that micro entrepreneurs Jombang interpret cost reduction as a side of cost savings to maintain existence by considering the customer aspects and values of religious religiosity in doing business, and interpret the social values in maintaining customer relations and social environment. This is found when they realize that not all content expenditure as a cost, but the existence of business continuity and religiosity owned make them realize that in the distribution of sustenance all there is to manage.
\end{abstract}

Keywords: cost reduction, micro entrepreneur Jombang, religious 


\section{PREMILINARY}

Cost reduction study is not a new thing anymore because many academics are interested in assessing cost reduction in terms of accounting. Cost reduction is part of strategy management that specifically deals with cost control programs. Where cost reduction is an effort to manage activities related to the production process that can reduce production costs by eliminating costs that should not have happened (Nikmatullah; 2014).

Cost reduction in the company, generally mechanical and ignore the principle of humanity to reduce costs that can be issued by the company and this is one of the weaknesses of the cost reduction if it really happened like this.

Related to the negative impact of cost reduction, Kasse and Damayanti (2016) explain that cost reduction strategies that focus on the causes of costs tend to consider short-term decisions and ignore long-term interests. The advantages of cost reduction is to minimize the costs out for unnecessary things, so the cost incurred by the company is not for the things that are wasteful and all structured.

In the micro business, the usual cost reduction is mixed with the cultural values that exist in the business environment is located because by combining existing cultural values we can approach with customers quickly and well. This is in line with research conducted by Efferin (2015). According to a research accounting based on local wisdom to bring the uniqueness of the phenomenon found in society to be an inspiration in order to bring change for the community. The difference between companies and micro entrepreneurs in using cost reduction is that companies are too targeted for high profits and for micro entrepreneurs are mostly prioritizing customer satisfaction and not targeting high profits

In Indonesia has a diversity of cultures and traditions. Culture on the island of Java is different from the culture in Sulawesi. Not a few residents who transmigrate from the region to other areas to do overseas with the aim of expanding the business and try something new in the new area as well.

Today many micro entrepreneurs are overseas from their home areas to other areas to further develop and expand their business. Research on overseas micro company has been raised by previous researchers. Previous research has focused on cost reduction on microentrepreneurs by continuing to bring their culture of origin to overseas by combining the two cultures into their business. Cost reduction as a costsaving way to produce products, they strive to maintain business continuity by considering the customer aspect and business existence is also done by upholding the cultural value of origin from overseas by Jamal (2017).

This study aims to see how the behavior patterns of micro entrepreneurs by using the concept of cost reduction in overseas areas in different environments with micro entrepreneur's culture in the perspective of micro entrepreneurs Jombang.

The results of this research are expected to complement the concept of cost reduction strategy conceptualized by, Kasee et. all (2016). This research has two contributions. Firstly, this research would like to see how the meaning of cost reduction in the application of micro business of bakso stalls that move from Jombang and open the shop in Gowa with various cultural differences in the area of origin and overseas area. Secondly, this research would like to see that cost reduction is not only mechanical in micro business with cost reduction aspect but it is to be seen how cost reduction is used as a pattern of management behavior in running a business while minimizing cost 
but still maintaining business existence in overseas.

\section{LITERATURE}

In the literature several definitions and concepts of cost reduction strategies can be found. Blocher et al. (2011) defines it as an effort to improve the company's performance in producing services or products at low cost. Harkness (2009) describes cost reduction strategies as a cost-reduction program to build lean, more agile, and more competitive businesses, Similarly Bragg (2010) and Cleverley et al. (2010) describes cost reduction as a variety of methods or tools used to reduce and eliminate unnecessary costs without reducing firm capability.

Cost reduction is seen as a profitboosting system through cost reductions (Ashraf \& Uddin 2016; Banker \& Byzalov, 2014; Barbole, Nalwade, \& Parakh, 2013). Cost reduction is part of strategy management that specifically deals with cost control programs. Cost control is the most important factor in organizational sustainability (the company).

In the aspect of accounting Cost reduction study is more focused on management strategies in applying cost reduction and measuring the impact of cost reduction program on company performance. There are various studies on the study of management strategies in implementing cost reduction among them by supriatna (2010), Iraswari \& Adam (2012) and Bouwens \& Steens (2016).

Supriatna's research (2010) finds cost reduction efforts in the garment industry done by reducing waste and continuous improvement. Iraswari \& Adam (2012) research through the implementation of lean manufacturing in small and mediumsized germen companies can reduce production costs and increase sales returns. Similarly, Bouwens \& Steens research (2016). Supriatna's research
(2010) finds cost reduction efforts in the germen industry done by reducing waste and continuous improvement. Iraswari \& Adam (2012) research through the implementation of lean manufacturing in small and medium-sized garment enterprises can reduce production costs and increase sales returns. Similarly, research conducted by Bouwens \& Steens (2016) using the Singel Minute Exchange of Die (SMED) technique for lean manufacturing decreased machine utilization in production activities.

Cost reduction impact studies on the company's performance are conducted by Mastilak (2011) and Wiyantoro \& Sabeni (2007). Mastilak Research (2011) using the Balanced Scorecard method found that cost reduction programs have a good impact on the perspective of financial performance, internal business perspective, and growth and learning perspectives, whereas customer perspectives that include customer satisfaction, customer growth and customer demand have an impact not good. In particular the negative impact of reduction as a cost control program is explained by Wiyantoro and Sabeni (2007). According to cost reduction, the impact of dysfunctional behavior management with the manipulation of data information.

Then on the negative impact of cost reduction, explained by Syarifuddin, Dayamanti, \& Mediaty (2015) that the cost reduction approach undertaken by the company is more mechanical by ignoring the values of humanity. they say cost reduction strategies that focus on the causes of costs tend to consider short-term decisions and ignore longterm interests. This is what causes the cost reduction program to have weaknesses and adversely affect the company's performance. by that, gave birth to the concept of holistic strategy by combining mechanical and system 
approach. The concept offers humans especially employees as the subject of cost reduction strategies for companies to be more humanist and long-term oriented.

Kasse and Damayanti (2016) explain that the organizational culture approach (company) is needed in the transformation of cost management. This is in accordance with the accounting research agenda offered by Efferin (2015). Where according to the accounting research based on local wisdom to bring the uniqueness of the phenomenon found in society becomes an inspiration in order to bring change for the community. And to realize the offer, sociology approach is needed as a cost reduction study analysis tool as an effort to bring the science of accounting to the reality of culture, religion, and spirituality (Mulawarman 2010, Triyuwono, 2012).

\section{RESEARCH METHODS}

This research uses qualitative methods because it aims to find the meaning of cost reduction in the perspective of micro entrepreneurs Jombang. Qualitative method is considered as an alternative research method or often called nonmainstream research method, from which it is understood that the qualitative method is in a superior position and the quantitative method is in the opposite position by Atmadja (2013: 122)

Qualitative research aims to interpret the object of research from the perspective of individuals or groups of individuals who are deemed to be derived from social or humanitarian problems by Cresswell (2013). According to him also with qualitative research all data or events in a social context embraced by individuals or groups of individuals can be found, including feelings, norms, beliefs, habits, mental attitudes, as well as in cultural context.

The main research considerations in this study identified in the interpretive paradigm are based on research objectives that explores the understanding of research subjects on how micro entrepreneurs of Jombang understand and interpret the concept of cost reduction in running their business. Some researchers (Burrell \& Morgan, 1994; Darmayasa \& Aneswari, 2015; Granlund \& Lukka, 2017) view that humans are free beings capable of creating social worlds, ideas, concepts, and theories. Social reality is viewed as relative and formed through interaction between man and his environment. Humans as individual beings are required role in understanding the social reality that is formed.

The focus of this research is the microentrepreneurs of today's bakso stalls who move or migrate from the city of Jombang to the city of Makassar and still maintain the values of the area of origin while maintaining the language and ethical style of Jombang community both in the context of product provision and in the application of business. This research is done naturally without engineering from informants or researchers so that what is understood by the subject is a phenomenon based on knowledge, experience and various other backgrounds. The subject of this research is the research informant which is seen to have a role in the management of micro business, especially the micro business owner who runs his business by bringing the taste from the origin region of Jombang.

In this research, the phenomenology approach is a qualitative research tradition based on philosophy and psychology and focuses on the experience ofhumanlife(sociology). Phenomenology approach is used to reveal the meaning of the concept of the experience and awareness of individual business owners of Bakso Masa Kini who move to the 
city of Makassar. This research is done naturally by using interview technique. Researchers conduct interviews at the time the owner finished selling because if done at the time of selling fear will disrupt the activity of the owner in doing his job.

This research focuses on one informant that is the key informant of the business owner of Bakso Masa Kini named Zuem Effendi which is where he is managing his family owned business located in Jombang. This meatball stalls business is located in an area that includes densely populated areas in Makassar which is also located near the campus of Alauddin Makassar Islamic University with the majority of students and the surrounding community. Informants from micro business Bakso Masa kini is now chosen because it meets the criteria as a manager of micro business which move from the origin to a new place and still bring the culture and taste from the region of origin.

The data analysis technique is done by phenomenology as conducted by Creswell (2013) below. (1) The stages begin by describing the experiences and personal awareness of the informant; (2) Make a list of important questions or notes for data deemed relevant to the problem; (3) Conduct a horizonal or take important statements to take its meaning. From this process filtered out the relevant horizons (themes); (4) Finding the essence of the found themes, then developed into the textual description (explaining the phenomenon experienced and acknowledged by the informant); (5) Creating a structural description (explaining how the phenomenon occurred); (6) Making an explanation of the narrative or essence of the essences of the background of awareness and experience by generating data in the form of field notes, whether in the form of interviews or observations into the text of research results and discussion. And this research there is a conclusion that is intended to answer the formulation of predetermined problems.

\section{RESULTS AND DISCUSSION}

The process of introducing researchers with informants began when researchers often eat to his stall, because the shop is famous for its taste of food is quite famous tasty and the price is quite affordable among students and the public, and who used to be located along the road Andi Pettarani, but because of the evictions then moved to Jalan Sultan Alaudin. The informant is the one who manages the micro business overseas of his aunt and uncle, who is Konita's mother and father Ludfi Nur Aji has three children.

The location of the shop which is located near the campus of Alauddin Makassar State Islamic University. In addition to being near the campus, stalls Bakso Masa Kini is on the road axis and in the vicinity are also many student contracts.

The researcher believes that Mas Zuem deserves to be an informant because he is an overseas micro-business manager relevant to this study. The idea of this research arose because of the proximity of researchers with Mas Zuem known by its customers as the origin from Jombang who moved to Makassar and manage the meatball stall owned by his family which was handed to him. It is this closeness which in the middle of the conversation occurs a process that passes the boundary between the seller and the buyer. Why is that? because in the conversation sometimes there are jokes and stories in everyday life in the joy of managing the meatball stalls that can be said to be quite well-selling bakso stalls in the neighborhood. Mas Zuem as a native Jombang who emigrated to Makassar to manage a meatball stall with a mandate from his uncle who has 
a glass shop business and his aunt who was originally a housewife The business of this bakso stalls started in 2011 which capitalize about Rp.15.000.000 including with the equipment of the shop and also cart used up to now. The typical meatballs recipe from this eatery from experimental results to the experiment resulted in a typical recipe run by Mas Zuem.

Mas Zuem is known by its customers as a business manager of Bakso Masa Kini. In addition, the difference intonation between customers and Mas Zuem is a blend of intonation of people Makassar and Jombang into something unique in the hearing. Researchers know Mas Zuem as an outsider from Jombang. From some of the many customers who greet him with Mas Ganteng because it can be said Mas Zuem it is the type of handsome man who sometimes tempted by his own customers. From here researchers see that the ethnic Javanese attached to the self-informant.

From the results of observations researchers toward informants in managing their business indicates a change in understanding of taxes. In the middle of the interview with Mas Zuem, the researcher asked about who wanted to be asked, "Excuse me, why is the bakso business called Bakso Masa Kini? because many people are wondering about the name of this shop ". And spontaneously Mas Zuem answered the question: "Yaa for wanting to forget the past is". this make, researchers laughed and asked again "Is this shop paying taxes ? "And Mas Zuem replied" yes, tax this stall in pay per day, a day that is paid about Rp.3.000 “. From this interview shows that paying taxes can be an additional cost but from this it is seen the obedience of the micro business that keeps paying taxes even though all cash out of the note is assessed as an expense.

Meatball business stalls are classified as micro business. This is based on his explanation that the highest sales range is Rp.2.500.000 which includes all the ingredients of stalls and salaries of employees. It is explained in the Law of the Republic of Indonesia No.20 Year 2008 regarding Micro, Small and Medium Enterprises that micro business is productive enterprise which individual / business entity fulfilling criteria (a) has net worth of Rp.50.000.00o (fifty million rupiah) excluding land and building forging business; or (b) having annual sales proceeds of Rp. 300,000,000 (three hundred million rupiah).

On the sidelines of the interview, the informant told of grief in managing the shop. According to him, which sometimes becomes a problem in running a meatball stalls business is the price of raw materials and main ingredients whose prices sometimes rise sometimes also fell. The increase in the price of materials does not necessarily follow the increase in the selling price because of the consideration of maintaining customer loyalty. Here's an excerpt from the interview:

"If the price of materials go up, the solution is just patiently and still maintain the taste and peculiarities of this shop, sometimes if you ride, we use from yesterday's sales. If there must be a profit and loss it's a fortune God set “.

From the above explanation shows that the cost of determining the achievement of profit, but still have limitations in practice. Approaches in cost management only use basic loading of raw materials as a component of cost of goods manufactured. This gives an understanding that micro entrepreneurs who have been down to earth and become dominant actors master the various fields, it works to expand the business by considering or charging labor costs into the determination of the cost of goods. The involvement of a workforce of only two people makes Mas Zuem as 
overworked, and the profits earned are also allocated to hire workers.

Mas Zuem as the manager of micro business of bakso stalls understands the substance of cost reduction itself. He considers that cost reduction is an appropriate form of cost management strategy in maintaining or increasing profits. According to the application of cost reduction requires expertise and experience in managing costs. Expertise in managing costs is required to keep the business profitable from the difference in sales with the cost incurred.

The informant realizes that the buyer has a very important role in sales because without the buyer the business will not run and the sustainability of his business. In making decisions is always based on the interests of customers because he is principled that "Buyer is King", which became a force in managing the business of this bakso stall. Concerns arise if the buyer does not like any more products offered by the stalls will be beribas on his business forward.

"If the price of expensive materials, such as if the chili is expensive, I make the chili in a little, customers usually ask why chili just a little, I just ask them for.. yaa " please just Patiently because chili is expensive" if asked like that customers also understand and not much protest, from the past until now the price in the bakso Masa Kini relatively cheap because for four years not changed worth Rp.8.0oo. worried if raised later customer will go, because the price is adjusted to the price of students. And we position ourselves as students so we must both understand “

From the above interview quotation shows that Mas Zuem in managing the meatball stalls realize that profit becomes the goal of business establishment but not necessarily also raise the price without considering the continuity of its business. There is awareness of the business manager of meatball stalls about the importance of cost reduction due to the increase in raw material prices. As an informant Mas Zuem realizes that the effort to raise the selling price of the menus in his stall is not an appropriate strategy especially without considering the background of his customers who are mostly students.

This understanding proves that at the level of micro entrepreneurs still have limitations in determining the selling price. Unstable raw material conditions are a challenge for managers and should seek solutions in case of price increases in the market. If raising the selling price of the first risk faced is dealing with the customer, because it can be ascertained if the price goes up and in another stall fixed with the price of the past then the customer will move to another shop. As the overseas informer realizes that it is better to take another strategy by reducing the cost of goods through a little reduction of the material but retaining the taste. Therefore the concept of cost reduction to be the right solution and should be considered in running a business. Based on the above explanation can be understood also that Jombang ethnic micro entrepreneurs interpret cost reduction as a strategy to manage financing (costing) products. This strategy aims to streamline costs to maintain business continuity.

Cost reduction is done with a view to maintain the ability of business to earn profit (profit). Nevertheless, it does not mean that profit becomes dominant without thinking of others and ignores the prevailing human values. The factor in business continuity is customer loyalty, without business customers not going the way and the existence of business in the circle will not be good without loyal customers. Cost reduction is also interpreted as a solution to be able 
to maintain the stability of the selling price in order to remain in accordance with market prices that occur in the micro-business environment.

In this study, researchers found three cost reduction strategies applied by informants as managers of micro business Jombang assessed as structural description (how phenomena / symptoms occur). These three strategies are first: avoid or minimize the presence of waste products to save raw materials, labor cost efficiency, and overhead cost efficiency.

Associated with business risk phenomena encountered, which often happens that not all menus are available, because sometimes one of the offered menu is not available anymore. Here's an interview: "Sometimes the pangsit already run out but still many who want to buy, we do not make a lot of later do not sell all so make a portion enough". From the above quotations informants avoid the advantages of products made here can be seen that this food stall uses the concept of cost reduction because if he makes the material too much and not sold then there will be additional ineffective cost and avoid the existence of waste products that become one of the management strategy. The following tells the informant: "we grind the meat itself once the milled ingredients then it can be used for two days, so time efficient and save energy, because if milling every day can overwhelm us". With the following statement also included in the strategy of minimizing waste products.

From these statements show that Mas Zuem actually realizes that the profitability of a food stall depends on the level of sales. The existence of its own satisfaction if the product sold out. However, it is not always due to the risks faced if the sale is not sold out, but the informant implements the cost reduction by storing the processed meat into the refrigerator to minimize the loss. Due to the presence of unsold waste products is considered as additional costs. Another problem that is also faced by businessman stalls meatballs or food is the uncertainty of the price of raw materials. Based on the researcher's observation of the object of research, cost reduction is defined as how to overcome the increase in raw material prices that impact on sales prices. So can the researchers conclude that the calculations and decisions taken by the manager is a very important thing in business continuity.

The business actor considers that the calculation of raw material costs becomes the basis for making decisions. Informants are also aware that customer purchasing power varies. Therefore, in order for the customer to continue to buy the sale then the overall business capital in this case which is spent for the purchase of raw materials into consideration to calculate the profit loss of sales.

"I can not bear to raise the price especially with students, I position as a student it's hard if the price of food is expensive".

In the above quotation can be seen that the manager of meatball stalls also consider the humanitarian side of the customer. Fluctuating raw material prices become its own challenge in managing meatball stalls. Raising the menu price can have an impact on consumer behavior and between the same business actors. Consumers, especially students will tend to find food that is relatively cheap and will move in a distant stall with a relatively cheap price. It can be seen that raising the selling price is not the right solution in the sales strategy when raw material prices soar, because maintaining the existence of trust from consumers is the most important thing to be considered by the manager of the meatball stalls. Because the purpose of meatball stalls business is to get a 
profit. Second, the implementation of cost reduction with direct labor cost efficiency. In considering the cost of labor the manager also has a reason for direct labor. "If there is a meatball order we work together and need extra work since we are only four" in this direct labor enough to minimize the cost and efficiency in work. Thought refers to the explanation of cost reduction as a method or tool used to cultivate and eliminate unnecessary costs without diminishing the capability. Third, the implementation of cost reduction with overhead cost efficiency. The informant considers the need for factory overhead efficiency in terms of transportation costs. The intended overhead is the cost of transportation for the purchase of raw materials and other auxiliaries. The informant realized that transportation cost had to be efficiency by buying raw material directly to raw material supplier. According to transport cost informants is quite expensive and can add costs to streamline costs. Based on the purchase of raw materials directly to suppliers can save costs. Here's the story:

"To save on transportation costs we buy raw materials using our own vehicles not with public transportation".

Efficiency is the ability to get things done right. In this case the informant can minimize overhead. Overhead costs are costs otherthan direct materials and direct labor but help in converting raw materials into finished products. Implementation of cost reduction through direct labor cost efficiency through the efficiency of direct labor costs and overhead is a reasonable solution to be undertaken. Stall entrepreneurs interpreted that the utilization of sufficient and not too much labor can minimize the cost of expenditure and work efficiency for every worker. Overhead costs are interpreted as avoidable costs, so they are not charged to the product. Of the three cost reduction strategies practiced by micro entrepreneurs abroad Jombang above shows the real phenomenon situation in the life of the owner of the food stalls that actually occur on the experience and awareness of informants as a strategy in cost management. From what happened above it can be understood that micro business management implements cost reduction strategy with traditional approach. It appears from the efforts taken by the food stall managers with a focus on direct cost savings and from the causes of costs. When examined from the subject of strategy that establishes human, especially the customer becomes the basis of cost reduction decisionmaking then this is the uniqueness in this approach.

The different approaches to cost reduction strategies that are mechanical, holistic, and that are implemented by micro entrepreneurs of Jombang overseas are located from the subject of strategy. The mechanical cost reduction strategy becomes an improvement of the management system as a subject directed todrive efficiency. Aholistic costreduction strategy is emphasized on two aspects that are targeted, namely management and human systems, especially employees, especially employees. The cost reduction strategy applied by micro entrepreneurs of Jombang overseas is subject to human, especially customer. This strategy is a complement to the holistic approach that makes humans a variable trigger in the cost reduction program. When in a holistic approach to make employees as internal parties become the trigger of cost, the micro entrepreneurs Jombang overseas make the customer as an external party worth considering for cost management. The birth of an external party to be a trigger in cost management makes the holistic concept offered by Kasse \& Damayanti (2016) further increase the value of the 
company and more humanist.

In themicro-friendly cost management approach based on customer activity, as the concept offered by Chapman, Kern, \& Laguecir (2014), Mickelsson (2013), and Wiang \& Miguel (2013) the concept of a customer-based activity is a humanist and long-term approach long. Value creation proceeds from the power of business managers interaction with their customers.

Sustainability micro business depends on the quality of business management interaction with its customers. The factor of the number of competitors in the same business and being in the close position so that keeping good relationship with the customer becomes the main consideration in decision making. Kasse \& Damayanti (2016) stated that the holistic cost reduction concept should incorporate organizational values as one of the focus of improvements to support the implementation of cost efficiency.

Orientation to the customer as the subject of the strategy is believed to be long-term oriented. Conversely, if the concept of cost is a feature of business culture that allows members of the organization to raise awareness of costs and impact on organizational capabilities, such as monitoring of expenditures, budgets and evaluation of alternative financial results.

\section{Essence of Experience and Awareness of Islamic Values as Basic Cost Reduction.}

The meaning of cost reduction described above is an unfortunate reality that is present in micro business circle of Jombang, as the theory present as a tool that can explain why that meaning can be born. From this study revealed that cost reduction is not only used by large, medium and small businesses only. Micro-entrepreneurs also make it a reasonable sousi to deal with various issues in cost management, including efforts to maintain relationships with customers and other business actors (Barbole, Nalwade, \& Parakh, 2013).

In the preceding explanation there is clearly an essentially (conceptual) assessment underlying that reality. Social construction is used to explain social reality as an attempt to describe phenomena in conceptual form. Cost reduction as a phenomenon that is understood, realized, and implemented for micro entrepreneurs, especially the stall meatball manager Jombang will be more clear when the conceptual review becomes part of the discussed. To draw the essential essence of the cost reduction phenomenon, researchers conducted interviews with informants. Can be seen from the following quote:

"Initially before wrestling directly I learned how my aunt makes meatballs if he is very prioritize cleanliness and to the customer should always be crowded. And if raising the price should be considered for the future it would be bad if the customer came then surprised by the price increase. Here too many sellers but that I consider it as a reference to be more excited rather than hostile to them the fortune is set so do not worry “

Based on the above statement it can be seen that the understanding of micro-micro Jombang is not inseparable from the influence of the culture and religion it embraces. As a micro-business knowledge obtained more from the surrounding environment. In managing the business there are three values used by Jombang overseas micro businesses, namely Jombang cultural values, Makassar cultural values and Islamic business ethics.

In general, cost reduction is defined as a form of cost control through cost savings (expenses) with a view to improving business performance. As an explanation of the meaning and implementation of cost reduction that has 
been described before, in the sidelines of interviews researchers found a different understanding. Here's the quote:

"If the matter of routine expenditures for the restaurant does not exist yet but if a kind of charity in our stalls it is in the cation to the needy for example there is a lack of money yaa okay or there are elderly who can be said as people who are less able to eat alone in the stall because sure that God will give more if we are diligent charity "

In the above explanation shows that micro entrepreneurs Jombang overseeing adheres to the principle of Islamic religion that he embraced in running a business. The habit of informants who often help others by feeding in stalls is not considered the addition of expenses or expenses to get the maximum profit. Precisely according to the above explanation of charity should be done for the business that runs get blessing. As explained in the Qur'an in Surah Al-Maidah verse 2, "And please help you in doing good and piety, and do not help in sinfulness and transgression, and fear Allah to Allah, very heavy punishment "(Surah Al-Maidah: 2).

The paragraph becomes a reference for business managers in running their business. With a right intention will help the sustainability of a business. Zakat, Infaq, and Shadoqoh are the obligations to be considered in making it an element of additional cost. Micro entrepreneurs of Jombang overseas have a strong life principle to always be a value in the movement that is able to adjust to the surrounding environment and also care about people in need.

Jombang culture with Javanese East ethnic has characteristic of dialect and their art, characteristic of Jombang people native and innocent nature make Jombang Java can quickly adapt well in different environment with original area. One of the tagline of Jombang people is his strong faith to be the value of the strong Islamic norms that exist in the management of the business run that is also known as a very honest person, as contained in the Qur'an (Q. Al.Mutaffififin: 1-3) "Accidents are great for those who cheat (that is) those who receive the doses of others whom they ask to be filled. And if they measure or weigh for others they reduce ".

From the explanation of the above paragraph is clearly said that we as business actors must be honest in running it so as not to get the wrath of Allah SWT. Efforts in fighting for honesty for parties and externally in running a business becomes an obligation for the customers.

The implications of this paragraph in the context of cost reduction can be interpreted that honesty in raising costs as a form of product prices should be presented to customers. Kasse \& Damanyanti (2016) that conceptually cost reduction is a combination of mechanical approaches based on organizational management systems and systems approach based on organizational values. Cost reduction is not only seen as a mechanical strategy used to engineer costs for the sake of the economy alone. Reflections on Islamic values, Jombang culture and Makassar culture show a local wisdom in cost management. This is manifested in the application of business ethics as taught from the three values. With this value, the meaning of cost reduction is not just as a bland cost management strategy with religious and social cultural values.

The findings of the concept of cost reduction in the view of micro entrepreneurs Jombang become a concept that has religious, social and cultural values. Finding the reality of cost reduction provides reinforcement of cost management concepts in accounting offered by Abdul Baki, 
Uthman, Olanrewaju, \& Ibrahim (2013). First, religious values are seen from the aspect of business spirit is worship (accountability to God). This spirit signifies that in Islam, profit is not the ultimate goal and the ultimate goal, but the means to achieve the goal. The purpose of life is Falah (prosperity in the world and in the hereafter). Second, the social cultural values appear in terms of the subjects that the focus of the strategy is the customer (consumer) and the environment. Customer-based costing assumes that customers contribute to revenue generation. Businesses can disrupt customers to be loyal so the returns are higher in the long run. Third, the economic value appears in the way of cost reduction implementation considering the efficiency side with the intention of increasing or maintaining the level of sales. This value is reflected in the management's cost-effectiveness in cost management.

The manifestation of this concept is the decision of cost management, especially cost reduction is expected to give impact of awareness and concern "honest" to what is managed by itself. This concept puts forward the ethical element in cost management. The values of local wisdom that exist in the company to be movement in cost management.

\section{CONCLUSIONS}

The approach taken in this research with phenomenology approach which found that Jombang overseas micro businessalsoapplycostreduction as a cost management strategy in management in its business. Jombang microenterprises mean cost reduction as a cost-saving way to produce the product in an effort to maintain the sustainability of their business. Cost reduction is done by minimizing the complementary strategy with the intention of maintaining the selling price with the same taste, or it can be interpreted as cost management using target coasting strategy.

Micro entrepreneurs in Jombang are aware that customers are the subject to be considered in determining the focus of cost reduction strategies. Therefore if an increase in price can affect customers. If there is an increase in raw materials, the complementary materials are reduced to keep stabilizing the price while maintaining the taste quality. This is based on the saying "Buyer is King". For the customer trust manager is included in the business continuity.

The reality found in this study is that overseas micro entrepreneurs of Jombang believe that not all are classified as expenditures that need to be streamlined. Zakat, Infaq, and shodoqoah are the obligations to be considered in making it an element of additional cost. Micro entrepreneurs of Jombang overseas have a strong life principle to always be a value in the movement that is able to adjust to the surrounding environment and also care about people in need. According to him expenditures get different treatment. That can be minimized in the expenditure of costs associated with raw materials, labor, and overhead.The concept of cost reduction is understood by micro entrepreneurs Jombang overseas based on cultural values of Jombang, local cultural values, and the value of business ethics in Islam. All three values are mutually integrated. In making decisions in the concept of cost reduction using the basic perspective of Islam by promoting honesty.

The limitation in this study is to focus only one informant so there is no comparison between each other. So it can not be ascertained intersubjectivity as a research approach because intersubjectivity is strengthened by the role of researchers who can be said as a customer and from this research got from 
the Micro entrepreneurs in Jombang of course. Therefore, to the next researcher to find more than one informant and informant directly from the business owner or looking for research subjects who have different business. It is recommended for the next researcher to explore the meaning of cost reduction for small, medium and large companies. Nevertheless, this research is expected to be useful for the development of study of accountancy science in the study of sociology.

\section{REFERENCES}

Abdul-Baki, Z., Uthman, A. B., Olanrewaju, A. A., \& Ibrahim, S. A. (2013). Islamic Perspective of Management Accounting Decision Making Techniques. Journalof Islamic Accounting and Bussiness Research, 4(2)203-219.https:// doi.org/10.1108/JABR-05-20120031

Alkatiri, Z., Rizal, J. J., \& Sohib, B. (2011). Accounting Decision Making Techniques. Journal of Islamic Accounting and Bussiness Research, 4 (2) 203-219. https:// doi.org/10.1108 JABR-05-20120031

Atmadja, T. A (2013). Struggle Methodology and Qualitative Research In the Science of Accounting. Journal of Professional Accounting, 3 (2),

Ashraf, J., \& Uddin, S. (2016). New Public Management Cost Savings and Regressive Effects: A Case from a Less Developed Country. Critical Perspectives oAccounting,433. https : / / doi.org/10.1016/j. cpa.2015.07.002

Barbole, A. N., Nalwade, Y. D., \& Parakh, S. D. (2013). Impact of Cost Control and Cost Reduction Techniques on Manufacturing Sector. Indian Streams Research Journal, 3(5),
1-8.

Blocher, E.J., D.E. Stout, dan G. Cokins. 2011. Cost Management: Strategic Emphasis (5 ed.). Mac Graw-Hill/ Irwin. New York.

Bragg, S.M. (2010). Cost Reduction Analysis: Tools dan Strategies. John Willey \& Sons. Canada.

Bouwens, J., \& Steens, B. (2016). Full-Cost Transfer Pricing and Cost Management. Journal of Management Accounting Research, 28(3), 63-81.https://doi. org/10.2308/jmar-51390

Cleverley, W. O. dan Cleverley, J. O. (2010). "Cost Reduction Identifying the Opportunities”. Healthcare Financial Management, Vol. 64, No. 3, pg.52-59.

Creswell, J. W. (2013). Qualitative Inquiry and Research Design: Choosing Among Five Approach (3rd ed.). Singapore: Sage Publications.

Darmayasa, I. N., \& Aneswari, Y.R. (2015). Interpretive Paradigm on Accounting Research Indonesia. Journal of Multiparadigm Accounting, 6 (3), 350-361. http://dx.doi.org/10.18202/jamal 2015.12.6028

Efferin, S. (2015). Accounting, Spirituality and Local Wisdom: Some Critical Research Agenda. Journal of Multiparadigm Accounting, 6 (3), 466-480. http://dx.doi.org/10.18202/jamal 2015.12.6037

Granlund, M., \& Lukka, K. (2017). Investigating Highly Established Research Paradigms: Reviving Contextuality in Contingency Theory based Management Accounting Research. Critical Perspectives on Accounting, 45, 63-80 https://doi.org/10.1016/j. cpa.2016.11.00

Harkness, P. (2009). "The Secrets of 
Successful Cost Reduction”. Supply Chain Management Review, Vol. 13 , No. 7 , pg. 50.

Iraswari, \& Adam, H. (2012). Lean Manufacturing Implementation: An Approach to Reduce Production Cost. Jurnal Akuntansi Multiparadigma, 3(1), 49-61.

Iqbal Nikmatullah \& Agus Widarsono. 2014. Analysis of cost reduction implementation in increasing profit. journal of accounting and financial research vol 2 (2), 352363.

Kasse, S. L., \& Damayanti, R. A. (2016). Holistic Cost Reduction Strategy: Integrating Mechanical and System Approaches. Journal of Multiparadigma Accounting, 7 (1) 10o.http: //dx.doi.org/10.18202/ jamal.2016.04.70

Mastilak, M. C. (2011). Cost Pool Classification and Judgment Performance. The Accounting Review,86(5),1709-1729.https:// doi.org/10.2308/accr-10103

Mickelsson, K. J. (2013). Customer Activity in Service. Journal of Service Management, (5),534-552.https:// doi. org/10.1108/09574090910954864

Mulawarman, A. D. (2010). Integration of Accounting Paradigm: Reflection on Sociology Approach in Accounting Science. Journal of Multparadigm Accounting, 1 (1), 155-171.

Supriatna, I. (2010). Review of Implementation of Target Costing and Cost Reduction Effort on Garment Industry. Journal of Economics, Finance, Banking, and Accounting, 2 (2), 291-311.

Syarifuddin, Damayanti, R., \& Mediaty. (2015). Cost Reduction Strategy in Corporate Values. In Meeting of Accounting Societies of Indonesia National Multiparadigm
(FRIEND). Makassar.

Triyuwono, I. (2012). Sharia Accounting:

Perspectives, Methodology, and Theory (2nd ed.). Jakarta: PT. Raja Grafindo Persada.

Wiyantoro, L., \& Sabeni, A. (2007). Relationship between Management Control Systems and Dysfunctional Behavior: National Culture as Moderating Variables. In the National Symposium on Accounting X. Makassar. 